\title{
Client's Readiness Assessment Success Factors for Outsourcing Software Projects
}

\author{
Azlina Abd Hamid ${ }^{\#}$, Zulkefli Mansor* \\ ${ }^{\#}$ Research Center for Software Technology and Management, Faculty of Information Science and Technology, \\ Universiti Kebangsaan Malaysia, Bangi, Selangor, 43600, Malaysia \\ E-mail:dykna@yahoo.com,kefflee@ukm.edu.my
}

\begin{abstract}
IT services such as software development, application maintenance, disaster recovery, help desk, network, and operations are critical and highly demanded to better support the operations and management of organizations, especially in the government sector. The government sector faces various problems in providing IT services due to constraints or lack of knowledge, skills, and expertise, human resource and technology. Thus, IT services need to be outsourced to overcome these problems. While the need for outsourcing has increased, reported weaknesses of the outsourcing activities are attributed to issues such as project rationale and the unclear role of the project team, lack of involvement of subject matter experts and users in the early stages, lack of control and lack of emphasis on quality. These issues indicate the low readiness level of the client's organization to take up outsourcing activities. Therefore, this study aims to analyze the contributing readiness factors that clients should comply with in order to ensure the success of outsourcing software projects. Systematic reviews and content analysis were employed in order to propose a conceptual model. There are 27 factors identified and classified into 9 dimensions. There are six internal dimensions were identified as contributing to the client's readiness such as strategy, people, organization culture, process, technology, and management whilst three other external dimensions include the government, market, and people. The outcome of this study is a software outsourcing readiness model that will assist software practitioners in designing effective outsourcing software project strategies. The model is important since the agencies have difficulty in addressing their readiness level as part of the implementation plan and to avoid project failure.
\end{abstract}

Keywords - organization readiness; client's readiness; outsourcing; software development

\section{INTRODUCTION}

As the business environment rapidly changes many companies are attempting to utilize IT outsourcing services to improve business operations and processes, achieve strategic goals, reduce costs, better focus on the company core business and enrich profitability [1], [2]. IT outsourcing provides both opportunities and risks to developing countries such as Malaysia. Effective and successful implementation of IT projects in the private and public sectors may offer opportunities and make economies more competitive [3]. In the government of Malaysia (GoM), although IT is generally not involved in creating competitive advantage, it is still viewed as a primary mechanism for creating more efficient service organizations [4]. According to The Malaysian Administrative Modernisation and Management Planning Unit (MAMPU) [5], the need has arisen for an IT service in the GoM to be outsourced or handled by external parties in order to fulfill the demand for better government services, quickly and effectively at anytime and anywhere. Recently, GoM has strengthened their objectives for IT outsourcing projects. The IT outsourcing projects must have viability aspects, resource optimization and cost effectiveness to support the needs of an agency. It aims to ensure that ICT projects have been implemented to provide added value and value for money, high impact and effectiveness to citizens while increasing the efficiency of public service delivery [6].

In Malaysia, the most common IT service outsourced is software development and industries prefer domestic outsourcing rather than offshoring [1]. Hence, software development outsourcing has low risks due to fewer offshore outsourcing undertaken. To ensure successful software projects, an organization must be concerned with not only technical solutions but also organizational issues, project management, and human behavior [7].

A study done by T.Pitsis [8] have discovered that approximately one-third of outsourced IT projects produced an ineffectual or negative outcome and more than $50 \%$ of outsourced IT projects were terminated before the contract expired and switched to other vendors or back sourcing. Failure outsourcing project being reported in GoM. A study on Public Sector ICT Projects 2015 [9] discovered that among the issues in government software projects include (i) 
unclear rationale for the project; (ii) the role of project team members is unclear; (iii) lack of control on project deliverables and amendments to / additional scope of the project; (iv) less emphasis on the quality of project deliverables; (v) lack of involvement of subject matter experts and the user in the early stages; (vi) less robust methods monitoring the project; and (vii) weak risk management. These issues represent the client's organizational problems. According to MAMPU [9], more than one type of problem faced in the course of outsourcing was concentrated in the areas of communication and organization, followed by difficulties in enforcing the terms of the contract. Prior studies also revealed that the same issues for outsourcing projects existed in the client's organization [10], [7]. Based on industry studies, 75\% of respondents admitted lack of confidence in the project success because of problems that involve attitudes toward projects other than issues related to requirement specifications and software development practices [10].

The successful adoption of software projects requires the readiness and capacity of all involved team players [11][12] and literature acknowledges organizational context as one of the determinants of successful software projects [7]. Literature shows that the readiness and assessment practices of all team players are different and need further investigation [13]. The general tenor is that customers can successfully exploit the outsourcing market in many ways such as in-house management, contract design, and relationship quality between outsourcer and service provider. However, some researches have addressed the organizational context - i.e., factors grounded within the outsourcer's organization as a determinant of successful outsourcing [14], [15]. To be organizationally ready to adopt and successfully implement (IT) innovation requires guidance on readiness prior to the adoption of software project outsourcing and justification thereof. Organizations that follow strategies to excel often adopt innovative practices. Thus it is important to identify readiness factor that helps the organization to assess their level of preparedness and gap before starting the outsourcing initiatives. This assessment helps the organization gain maximum benefits for the outsourcing engagement and facilitate software project outsourcing.

This paper consists of 5 sections. Section I discuss the background of this study including the issues and problems of customer organizations for outsourcing. Section II discuss the IT outsourcing and client's readiness in outsourcing software projects. Section III elucidates the methodology used in the study. Section IV presents the findings of the work. Lastly, section V concludes the paper with a summary of the findings and recommended future work.

\section{MATERIALS AND METHODS}

\section{A. Overview of Software Project Outsourcing}

Software outsourcing is an outsourcing arrangement for a wide variety of software services including new development, legacy systems maintenance, offshore programming, management of packaged software and staff augmentation [16]. Outsourcing arrangement is a decision taken by an organization to contract out activities to a third party supplier, who in exchange provides and manages services for monetary returns over an agreed time period [17]. Software outsourcing has changed its format from simple specialization (automation) to business process outsourcing or software service providers. This is based on D. Brown [18], the state of new technology and concepts introduced to replace legacy outsourcing such as business process as a service (BPaaS), and software as a service (SaaS). This new form of services illustrates the maturity of IT outsourcing.

Consequently, outsourcing practice has moved from a niche technology management tool to a mainstream and a strategic weapon for many firms. There are various definitions that relate to outsourcing as shown in Table 1. Based on the various terms in outsourcing, there are features that can be collectively identified through the following three areas that contribute to the success of the outsourcing project.

- Size and duration of contract;

- Transfer of assets; and

- Breadth of responsibilities.

TABLE I

OUTSOURCING DEFINITION COMPARISONS BASED ON V. SAINI AND D. C. CHOU [19]

\begin{tabular}{|c|c|}
\hline Source & Outsourcing terms /definition \\
\hline $\begin{array}{l}\text { Human } \\
\text { Resource } \\
\text { Outsourcing } \\
\text { Association } \\
(2003)\end{array}$ & $\begin{array}{l}\text { Outsourcing is defined as the contracting of } \\
\text { one or more of a company's business processes } \\
\text { to an external service provider to help increase } \\
\text { shareholder value, by primarily reducing } \\
\text { operating costs and focusing on core } \\
\text { competencies }\end{array}$ \\
\hline $\begin{array}{l}\text { Daniel } \\
\text { Minoli } \\
(1995)\end{array}$ & $\begin{array}{l}\text { Turning over of information systems and/or } \\
\text { communications functions, as a whole or in } \\
\text { part, to a third-party contractor as a solution to } \\
\text { the challenge, problem, and expense of } \\
\text { creating and running a corporate information } \\
\text { enterprise }\end{array}$ \\
\hline $\begin{array}{l}\text { Geoff Kilby } \\
\text { (1993) }\end{array}$ & $\begin{array}{l}\text { A contractual relationship where an external } \\
\text { organization takes responsibility for } \\
\text { performing all or part of an agency's } \\
\text { Information Technology functions. This can } \\
\text { involve a partial or complete transfer of staff } \\
\text { and/or resources }\end{array}$ \\
\hline $\begin{array}{l}\text { Dianne } \\
\text { Northfield } \\
\text { (1992) }\end{array}$ & $\begin{array}{l}\text { An arrangement whereby a third party } \\
\text { provider assumes responsibility for performing } \\
\text { information systems functions at a pre- } \\
\text { determined price and according to } \\
\text { predetermined performance criteria }\end{array}$ \\
\hline
\end{tabular}

This study aims to discover the organization's responsibilities in light of the client's outsourcing engagement.

IT outsourcing dimensions are classified into IT services, delivery model, degree of business relevance, level of outsourcing, time frame and organizational form (see Table 2 ) [20]. 
TABLE II

IT OUTSOURCING DIMENSION BASED ON K. KRONAWITTER [20]

\begin{tabular}{|c|c|}
\hline $\begin{array}{l}\text { IT Outsourcing } \\
\text { Dimension }\end{array}$ & Type \\
\hline IT Services & $\begin{array}{l}\text { Disaster Recovery, Client Server, } \\
\text { Midrange\& mainframe, Network, End User } \\
\text { PC, Helpdesk, Project Management, } \\
\text { System development, Application } \\
\text { maintenance, System architecture }\end{array}$ \\
\hline $\begin{array}{l}\text { Level of } \\
\text { Outsourcing }\end{array}$ & Total, Selective \\
\hline Time frame & $\begin{array}{l}\text { Short term (less than a year), Middle term } \\
(1-3 \text { year), Long-term ( more than } 3 \\
\text { years) }\end{array}$ \\
\hline $\begin{array}{l}\text { Degree of } \\
\text { business } \\
\text { relevance }\end{array}$ & $\begin{array}{l}\text { Knowledge process, Business process, } \\
\text { Application, Infrastructure }\end{array}$ \\
\hline $\begin{array}{l}\text { Delivery } \\
\text { model } \\
\text { (Geographical) }\end{array}$ & Onsite, Onshore, Nearshore, Offshore \\
\hline $\begin{array}{l}\text { Organizational } \\
\text { form }\end{array}$ & $\begin{array}{l}\text { External, Equity holding, Joint venture, } \\
\text { Captive/ spin-off, Cooperative sourcing, } \\
\text { Facilities sharing }\end{array}$ \\
\hline
\end{tabular}

Private companies in Malaysia spend between RM100,000 to RM1 million for outsourcing software development projects. Meanwhile, the public sector spends between RM50,000 to RM11.75 million for each software development project under the 10th Malaysia Plan [1], [9]. It gives the indication the size of software projects in Malaysia between public sector and private sector are significantly different in the cost. Public sector outsourcing projects are riskier than private sector since more fund has been allocated for the outsourcing effort.

IT services outsourcing for the private sector software development represents the top service, followed by software maintenance services and end user PC support. Software development also constitutes a high percentage of IT services outsourcing in the public sector, followed by maintenance and upgrading ICT software and infrastructure [1].

In planning characteristics, local companies and the GoM develop strategic planning within a short-term, medium-term and long-term framework. Short term and middle term arrangements are most preferred with few for long-term arrangements. Short-term usually involves processes that produce results within a year, while companies aim for medium-term results that take several years and long term plans that set the overall goals of the company at four or five years in the future.

Studies show that private companies and public organizations in Malaysia choose domestic outsourcing for outsourcing software development except for midrange and mainframe services. This could be due to various reasons, one of which is that government-linked companies have to award contracts to local vendors [21].

\section{B. Readiness Assessment}

Readiness assessment definition and objectives vary when an organization prepares to embark on new projects. According to PWC [22], readiness assessment is an outsourcing evaluation strategy, an opportunity analysis, a risk assessment and an overall viability assessment of organization readiness to outsource. Through the gaps identified within the organization, the readiness assessment affords the opportunity to remedy the gaps either before or as a part of the implementation plan. Thus, this effort can be seen as part of quality improvement.

Various studies have been conducted which directly or indirectly emphasize the factor or elements that organizations should consider and react as a player in the outsourcing activities [4] There are also some studies on the readiness approach [14], [15] and models to measure either the success and/or readiness towards certain concepts. The purpose of the model varies depending on the concepts that are going to be taken. Critical industries such as health and construction use IT extensively to support its long operation processes. These organizations put much emphasis in assessing their organizational readiness before making any IT investment decision [15], [23]. Based on the analysis, the identified factor and elements used by health institutions to assess their readiness varies [24], [15] and there is no specific model that is used as a guide. Detailed discussion on the readiness factor identified through literature will be covered in the discussion section.

\section{Method}

This study examines the client's readiness factor by analysing the relevant literature in order to identify the contributing factors (internal and external) for the successful software project domestic outsourcing. For factors identification, a systematic reviews process and content analysis are implemented. A systematic review is a defined as a methodical way of identifying, assessing, and analyzing published primary studies in order to investigate a specific research question for this studies. On the other hand, the use of content analysis is aimed at the formulation of a conceptual process model that provides some understanding of current practices. In finding, evaluating, and summarizing all available evidence on software development outsourcing, a systematic review may provide a greater level of validity in its findings. A systematic review protocol is designed first in order to perform the systematic review. Fig. 2 below are research design for this studies.

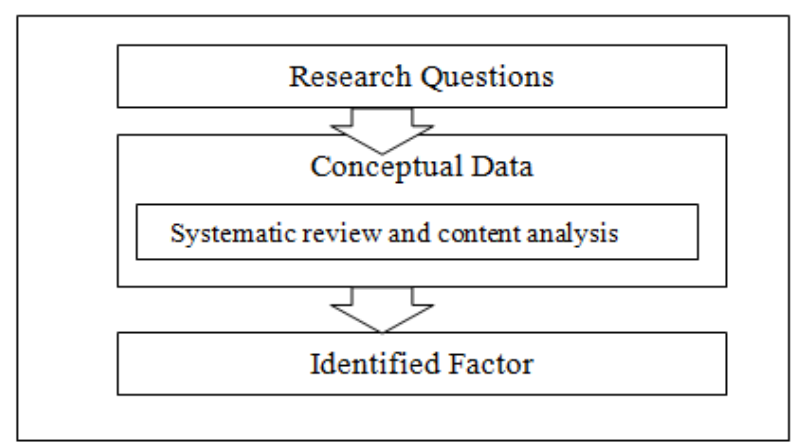

Fig. 2 Client's readiness conceptual model in outsourcing software development

In conducting systematic review there are several steps that have been taken which is formulation of research questions, identification of the research resources, set the inclusion and exclusion criteria, and set the publication quality assessment. The are 28 number of articles have been 
selected after excluding irrelevant studies. Below are details of the steps.

1) Formulation of Research Questions: The case studies for this research comprise the selected agencies within the Government of Malaysia that practice software development outsourcing. In general, the study aims to answer the following research questions:

- RQ1 What are the contributing factors for client's readiness to carry out software development outsourcing?

- RQ2 What are the elements that are being measured from the identified factors?

2) Research Resources: Six electronic database resources were used to primarily extract the data for review in this research. The databases used are IEEEXplore, ScienceDirect, Google Scholar, Web of Science and Scopus. The selection of online databases was based on personal knowledge of databases that indexed "Organization readiness" or "Client's readiness" or "Outsourcing" or "development" studies and the list of the available online database subscribed by the University's library. Searching techniques and refinement were used for published journal papers and conferences between 2011 and 2016. For searching techniques, the search string will be based on research questions. The usage of Boolean OR and Boolean OR also allowed synonyms and world class variants of each keyword applied.

Below is the list of search strings used to search for publications from selected journals:

- ("client's readiness" OR "organization readiness") AND factor AND outsourcing AND development

- ("readiness assessment") AND outsourcing AND development

3) Research Inclusion and Exclusion Criteria: The aimed articles constitute the readiness assessment model from the organization's (client's) perspective that involve these discussions:

- Related issues on outsourcing development success that relates to the organization (clients)

- Factors, models, assessment, development and related issues on organizational readiness for outsourcing software development

- Motives, goals and reason to adopt a readiness assessment model

- Strategies and methodologies for adoption,

- Available online database subscribed by the University's library

- Published journal papers and conferences

Non-English articles, non-matching articles, and articles that are not fully in English are excluded from the targeted articles.

4) Publication Quality Assessment: The measurement of quality was performed after the final selection of publications and was simultaneously assessed at the time of data extraction. The criteria of a quality publication include a clear explanation of how the factors and elements for client readiness are identified in the outsourcing business and that the author is not biased towards publishing positive results than negative results. The outcomes after conducting the selection based on systematic review guidelines are shown in Table 3.

TABLE III

Outcome After Conducting SELECtion Based On Systematic REVIEW GUIDELINES

\begin{tabular}{|l|l|}
\hline Number of articles retrieved from journals & 186 \\
\hline $\begin{array}{l}\text { Number of articles after screening of title, abstract and } \\
\text { keywords \& duplicate studies }\end{array}$ & 158 \\
\hline Number of articles after excluding irrelevant studies & 28 \\
\hline
\end{tabular}

Content analysis (qualitative research method) was then used to analyze data gathered from the selected articles. Content analysis is a research method that uses a set of procedures to make valid inferences from the text. Moreover, it can be used to analyze verbal or visual communication language and it has several advantages in comparison with other research methods [25]. The purpose is to identify the common categories factor/data in the contents. The processes were carried out continuously throughout the study until the data reached its saturation period.

\section{RESULTS AND DISCUSSION}

According to the analysis, the factors identified are classified into external factor and internal factor. There are 27 factors identified in total and all this factor have been classified into 9 dimensions according to their characteristics. The analysis also identified the elements to support the identified factor for organization readiness assessment for outsourcing effort. Table 4 below lists the general set of factors identified from the systematic review and content analysis conducted:

TABLE IV

FACTORS FOR CLIENT'S READINESS IN OUTSOURCING SOFTWARE DEVELOPMENT

\begin{tabular}{|c|c|c|c|}
\hline $\begin{array}{l}\text { Readiness } \\
\text { Dimension }\end{array}$ & $\begin{array}{l}\text { Readiness } \\
\text { Factor }\end{array}$ & Elements & Author \\
\hline \multicolumn{4}{|c|}{ EXTERNAL FACTORS } \\
\hline Government & $\begin{array}{l}\text { Legislation or } \\
\text { guidelines }\end{array}$ & $\begin{array}{l}\text { legislation or } \\
\text { guidelines that } \\
\text { organizations } \\
\text { must conform } \\
\text { to }\end{array}$ & $\begin{array}{l}{[11],[21],} \\
{[5]}\end{array}$ \\
\hline \multirow[t]{2}{*}{ Market } & \multirow[t]{2}{*}{ Technology } & Hardware & $\begin{array}{l}{[11],[26],} \\
{[20],[21],} \\
{[5]}\end{array}$ \\
\hline & & Support & [21] \\
\hline People & $\begin{array}{l}\text { Capability and } \\
\text { maturity }\end{array}$ & $\begin{array}{l}\text { Capability and } \\
\text { maturity of } \\
\text { external people } \\
\text { involved in the } \\
\text { project (eg: } \\
\text { customers, } \\
\text { partners) }\end{array}$ & {$[11],[27]$} \\
\hline \multicolumn{4}{|c|}{ INTERNAL FACTORS } \\
\hline Strategy & Financial & $\begin{array}{l}\text { Financial } \\
\text { feasibility } \\
\text { study }\end{array}$ & {$[28]$} \\
\hline
\end{tabular}




\begin{tabular}{|c|c|c|c|}
\hline $\begin{array}{l}\text { Readiness } \\
\text { Dimension }\end{array}$ & $\begin{array}{l}\text { Readiness } \\
\text { Factor }\end{array}$ & Elements & Author \\
\hline & & $\begin{array}{l}\text { Financial } \\
\text { investment }\end{array}$ & $\begin{array}{l}{[15],[5],} \\
{[29],[28]}\end{array}$ \\
\hline & Time & $\begin{array}{l}\begin{array}{l}\text { Project } \\
\text { duration }\end{array} \\
\end{array}$ & $\begin{array}{l}\text { [21], [15], } \\
{[29]}\end{array}$ \\
\hline & & $\begin{array}{l}\text { Time } \\
\text { commitment }\end{array}$ & [15], [29] \\
\hline & Resource & $\begin{array}{l}\text { Resource } \\
\text { management }\end{array}$ & {$[14]$} \\
\hline & Approval & Approval & [29] \\
\hline & $\begin{array}{l}\text { Contingency } \\
\text { Plan }\end{array}$ & Exit strategy & [29], [30] \\
\hline \multirow{9}{*}{$\begin{array}{l}\text { Organizatio } \\
\text { n Culture }\end{array}$} & \multirow{3}{*}{$\begin{array}{l}\text { Leadership and } \\
\text { management }\end{array}$} & Leadership & [31], [32] \\
\hline & & Support & {$[14],[15]$} \\
\hline & & Capability & $\begin{array}{l}{[12],[13],} \\
{[30]}\end{array}$ \\
\hline & \multirow[t]{3}{*}{$\begin{array}{l}\text { Business-IT } \\
\text { alignment }\end{array}$} & $\begin{array}{l}\text { Business } \\
\text { strategy }\end{array}$ & [11] \\
\hline & & IT Strategy & [11] \\
\hline & & $\begin{array}{l}\text { Organizational } \\
\text { structure }\end{array}$ & {$[10],[17]$} \\
\hline & \multirow[t]{3}{*}{ Commitment } & $\begin{array}{l}\text { Project } \\
\text { Awareness }\end{array}$ & [7], [24] \\
\hline & & Project View & [7], [24] \\
\hline & & Involvement & $\begin{array}{l}\text { [7], [24], } \\
{[33]}\end{array}$ \\
\hline \multirow[t]{6}{*}{ People } & Knowledge & $\begin{array}{l}\text { Knowledge in } \\
\text { IT and process }\end{array}$ & [7], [23] \\
\hline & \multirow[t]{2}{*}{$\begin{array}{l}\text { IT skill and } \\
\text { expertise }\end{array}$} & $\begin{array}{l}\text { IT skill in the } \\
\text { technology } \\
\text { used }\end{array}$ & [7], [23] \\
\hline & & $\begin{array}{l}\text { Expert / } \\
\text { champion in } \\
\text { business } \\
\text { process }\end{array}$ & [7], [23] \\
\hline & Experience & $\begin{array}{l}\text { Experience } \\
\text { with ITO }\end{array}$ & [7], [23] \\
\hline & Capability & $\begin{array}{l}\text { Capability to } \\
\text { adapt to } \\
\text { changes and } \\
\text { learn }\end{array}$ & [7], [23] \\
\hline & $\begin{array}{l}\text { Roles and } \\
\text { responsibilities }\end{array}$ & $\begin{array}{l}\text { Aware of roles } \\
\text { and } \\
\text { responsibilities }\end{array}$ & $\begin{array}{l}{[7],[23],} \\
{[34]}\end{array}$ \\
\hline \multirow[t]{4}{*}{$\begin{array}{l}\text { Process and } \\
\text { procedures }\end{array}$} & Process & $\begin{array}{l}\text { Process } \\
\text { maturity }\end{array}$ & $\begin{array}{l}\text { [5], [29], } \\
{[14],[23],} \\
{[35]}\end{array}$ \\
\hline & $\begin{array}{l}\text { Development } \\
\text { approach }\end{array}$ & $\begin{array}{l}\text { Development } \\
\text { plan }\end{array}$ & [28], [29] \\
\hline & $\begin{array}{l}\text { Documentation } \\
\text { and resource }\end{array}$ & $\begin{array}{l}\text { Availability of } \\
\text { resources }\end{array}$ & [28], [29] \\
\hline & Compliance & $\begin{array}{l}\text { Compliance to } \\
\text { available } \\
\text { policy }\end{array}$ & [29] \\
\hline \multirow[t]{2}{*}{$\begin{array}{l}\text { Information } \\
\text { Technology }\end{array}$} & Requirements & $\begin{array}{l}\text { Functional } \\
\text { requirements } \\
\text { and non- } \\
\text { functional } \\
\text { requirements } \\
\text { (QoS) } \\
\end{array}$ & {$[14],[31]$} \\
\hline & Security & $\begin{array}{l}\text { Management } \\
\text { Information } \\
\text { Security }\end{array}$ & [31], [29] \\
\hline
\end{tabular}

\begin{tabular}{|c|c|c|c|}
\hline $\begin{array}{l}\text { Readiness } \\
\text { Dimension }\end{array}$ & $\begin{array}{l}\text { Readiness } \\
\text { Factor }\end{array}$ & Elements & Author \\
\hline & $\begin{array}{l}\text { Support and } \\
\text { operation }\end{array}$ & $\begin{array}{l}\text { IT Staffing for } \\
\text { support and } \\
\text { operation }\end{array}$ & {$[14],[13]$} \\
\hline & 1 - it & $\begin{array}{l}\text { Layered } \\
\text { structure }\end{array}$ & {$[36],[28]$} \\
\hline & Arcnitecture & $\begin{array}{l}\text { Service } \\
\text { orientation }\end{array}$ & [36] \\
\hline & & $\begin{array}{l}\text { Hardware/soft } \\
\text { ware basic }\end{array}$ & $\begin{array}{l}{[5],[13],} \\
{[36]}\end{array}$ \\
\hline & Infrastructure & $\begin{array}{l}\text { External data } \\
\text { exchange }\end{array}$ & [36] \\
\hline & & $\begin{array}{l}\text { Internal } \\
\text { connectivity }\end{array}$ & [36] \\
\hline & Services level & $\begin{array}{l}\text { Identified } \\
\text { service level } \\
\text { required }\end{array}$ & $\begin{array}{l}\text { [21], [37], } \\
{[7]}\end{array}$ \\
\hline & $\begin{array}{l}\text { Quality } \\
\text { Assurance }\end{array}$ & $\begin{array}{l}\text { Verify quality } \\
\text { of deliverables / } \\
\text { services }\end{array}$ & {$[21],[15]$} \\
\hline \multirow[t]{3}{*}{ Management } & Risk & $\begin{array}{l}\text { Risk } \\
\text { assessment and } \\
\text { management }\end{array}$ & [2], [7] \\
\hline & Project & $\begin{array}{l}\text { Project } \\
\text { Management } \\
\text { and monitoring }\end{array}$ & [29], [7] \\
\hline & Vendor & $\begin{array}{l}\text { Vendor } \\
\text { Management }\end{array}$ & $\begin{array}{l}\text { [29], [7], } \\
{[30]}\end{array}$ \\
\hline
\end{tabular}

The factors identified were mapped into assessment phase as a conceptual model in application and development outsourcing as in Fig. 2. According to S. F. Martin et al [13], many researchers have conducted studies on outsourcing success without producing a common definition of what exactly constitutes outsourcing success. Based on $\mathrm{M}$. Jørgensen [38] studies on the characteristics of projects with success in delivering client benefits, the successful outsourcing project can be achieved when the organization is able to manage the triple constraints of scope, time and money in delivering quality services or products. GoM emphasizes on function, quality and cost for a government project and it was a part of successful projects [39]. Yet, various other factors may influence the effort.

\section{A. External Readiness Factor}

Based on the analysis, a number of external factors may influence the success of software project outsourcing and those factors have been categorized into 3 dimension which is government, market, and people.

1) Government: Currently, several governments in developing countries such as Malaysia, Singapore, South Korea, Hong Kong, have enacted legislation or guidelines that organizations must conform to in outsourcing software development [40]. Thus, imposing the guidelines indirectly shapes the outsourcing practices of the country. For an example in the GoM, an official circular stated that public agencies must give priority to local experts and service 
providers for outsourcing projects [21] and studies showed that the statistics were positively in line with such requirements [1].

2) Market: In the market readiness context, the demand, and supply concepts determine the future growth prospects and increased the level of confidence for clients. The main indicators of market readiness are related to products (hardware and software) such as ease of substitution, steady arrival of a competing product, the issue of product obsolescence (i.e. how quickly a product becomes obsolete) and continuous change in technology (i.e. the production process) [11].

3) People: In the people context, the external parties beyond the organization such as partners, vendors, customers affected by the project also need to be assessed according to their capabilities and maturity [11], [27]. Their readiness or changes in system interface, business process or practices may influence the success factor.

\section{B. Internal Readiness Factor}

Internal factors in this study relate to the client's organizational control and responsibilities. The client's organization is defined by much more than organizational structure, job titles, role and reporting structure. Besides organizational structure, the multiple dimensions spanning organizational culture, people, processes, and technology are represented within it [41]. In general, there are 24 identified internal factors in literature have been identified and classified into six readiness dimensions according to their characteristics. These are organizational culture, people, process, and procedures, IT/Technology, strategy, and management.

1) Strategy: Strategy readiness is how organization plan for the outsourcing project. For government agencies, it is important that every project gets an approval from Government IT and Internet Committee (JITIK) before starting the project [6] because all government project ICT will be approved, release fund and monitor by this committee. Strategy readiness also reflects on how financial is determine and how much investment for the project without proper study and enough budget, the project will face a problem during execution of the project. In project planning, it is important to set the duration of the project and organization must have a target when the outcome of the project will be implemented. It is also crucial to set time commitment needed for the project especially that reflects the stakeholder and domain expert in order to get the buy-in and ensure the project execute smoothly. A part of strategy readiness, it is also important to access the available resource for the project because it may impact the project and it might incur the cost of the project. Organization also must have a contingency plan if there is contract termination with the service provider, either on expiry or prematurely. Organization must be able to have all IT information and assets promptly removed or destroyed [42].

2) Organization Culture: Organization culture is the way of managing an organization in the effort to improve the effectiveness and efficiency of its overall performance [33]. In organization culture identified factors need to be assessed in terms of leadership and management, their strategic alignment between business and IT and commitment.

For leadership, the organization must have central leadership, clear mandate and shared understanding [31]. Gain the commitment from a strategic level and management is important to get support from them. The way business management demonstrates competence and involvement in IT field and also ability to deliver a strong message that will encourage staff to meet project goals [12], [13].

In business IT alignment factor, an organization can assess their readiness of business strategy in form of how business and IT collaborate and IT involvement in business strategy development. The form of communication in organization structure also gives an impact towards project where good communication through ongoing of exchange of information can help to achieve expectations and satisfaction and avoid conflicts [17].

Studies by J. Joharo and E. Nazir [33] reported that organization can achieve every aspect of performance if organization's well-founded culture, therefore, to enhance their organizational success most organizations started to reevaluate their current practices. Furthermore, J. Joharo and E. Nazir also identified commitment is also areas in organization culture that should be assessed. Organization commitment is defined as-as an employee's identity and belief in the organization's goals and values, willing to exert considerable effort on behalf of the organization, loyal to the organization, have strong desire and feel oblige to maintain membership with the organization over the long term [33]. Organization commitment can be assessed in many ways. In practice, the Stratis Health Information Technology Services [24] assess their organization in a way project is viewed (benefit realization and trust), project awareness (degree of awareness about the project within the organization) and level of involvement in the project.

3) People: To plan and execute a successful outsourcing transaction, a factor that relates to people dimension are very important. From the analysis, the people within the organization should pose necessary competencies, practical experience, baseline information, knowledge business processes and IT, technical, experience and capability in place and people that involve in the project must understand their roles and responsibilities. Without these, you run the risk of falling short of implementing a successful outsourcing relationship and realizing expected benefits.

4) Process and Procedures: Process and procedures need to be in place to assist the development effort. The areas that can be assessed in this context are process maturity, development plan, availability documentation and resource and also compliance with an available policy. ITIL describes process maturity as a measure of the reliability, efficiency, and effectiveness of a process [14]. There are various current standards that can be used as a guideline software engineering process like CMM, ISO, and PMI. An organization can use this standard rules in managing outsourcing projects and in management practice of IT. 
Having this guideline can help organization to build up their capability and maturity in the management of IT outsourcing.

5) Information Technology (IT): IT readiness reflects the organization technical resource for support and operation, existing architecture and infrastructure, management in information security, intended service level, and skills in verifying and validate the quality of deliverable service. For the outsourcing software project, it is important that to be clearly defined the functional requirement and nonfunctional requirement to enable the project. The requirement resource must also available to support the effort. This is to avoid the additional unintended requirement that may affect the project.

6) Management: In management, the key factor that should be assessed are risk management, project management, and vendor management. Organization must have an ability to assess project risk and plan to mitigate the risk. For project management and monitoring, client readiness can be assessed through project management practice, standards used and discover the mechanism project are going to be monitored. For outsourcing projects, vendor management is an important factor to ensure the outcome of the project can be delivered on time and in a good quality. An organization also can be assessed regarding their ability to manage vendor selection, ability to preserve established relationships with the vendor, handle conflict resolution process, the capability to monitor the performance of the service provider and audit the service provider to assess its compliance with your policy, procedures, security controls, and regulatory requirements.

\section{CONCLUSIONS}

Outsourcing practices have led to success and failure stories. Many types of researches have addressed readiness aspect in both vendor and client perspective, but in client's readiness the imposing factor in practise are vary and there are no guidelines in GoM to assess the agencies readiness for the outsourcing projects. This article addressed the issues concerning the outsourcing factors that influence client's readiness before participating in outsourcing activities as one unified process. The article represents the input (factor) in the development of the client's readiness assessment model that can be used to identify the client's level of readiness. Each factor is gathered from systematic literature from the identified databases. As a result from the analysis, there are 27 factors identified.

As a future work, an empirical study will be conducted to support the analysis and then all those factors will be formed as a model to provide guidelines for the implementation of software project outsourcing in Malaysia public sector. Finally, the proposed model can also be applied the model will be applied to outsourced IT projects within organizations of different industries, sizes, and countries in order to validate the usefulness of the model in terms of increasing the success rate of the outsourcing.

\section{ACKNOWLEDGMENT}

The authors would like to thanks, Faculty of Information Science and Technology, Universiti Kebangsaan Malaysia by giving the authors an opportunity to conduct this research. This research is funded by Universiti Kebangsaan Malaysia under Fundamental Research Grant Scheme FRGS/1/2014/ICT07/UKM/02/3 and Research Development Fund (DPP-2015-019).

\section{REFERENCES}

[1] A. Sulaiman, N. I. Jaafar, and L. H. G. Beng, "IT Outsourcing Trends in Malaysia: An Insight," no. October, pp. 1-18, 2015.

[2] M. Vaheed, M. Tahir, and M. Burhanuddin, "ICT Project Failure in Government Sectors: Factors from Vendors Perspective," J. Sci. Res., vol. 23, pp. 2706-2712, 2015.

[3] Unctad and B. a N. Ki-moon, Information economy report 2012: the software industry and developing countries. 2012.

[4] N. Samsudin, R. Hashim, and S. Fuzi, "Electronic Government Outsourcing Issues in Malaysia," J. Outsourcing Organ. Inf. Manag., vol. 2013, pp. 1-10, 2013.

[5] MAMPU, "Garis Panduan IT Outsourcing Agensi-Agensi Sektor Awam," Jab. Perdana Menteri, p. 26, 2006.

[6] MAMPU, "Garis Panduan Permohonan Kelulusan Teknikal dan Pemantauan Projek Teknologi Maklumat dan komunikasi (ICT) Agensi Sektor Awam," Surat Pekelil. Am Bilangan 3 Tahun 2015, pp. $1-5,2015$.

[7] J. M. Verner and L. M. Abdullah, "Exploratory case study research: Outsourced project failure," Inf. Softw. Technol., vol. 54, pp. 866886, 2012.

[8] T. S. Pitsis, M. Kornberger, and S. Clegg, "The art of managing relationships in interorganizational collaboration," Management, vol. 7, pp. 47-67, 2016.

[9] MAMPU, "Kajian Pelaksanaan Projek ICT," pp. 1-14, 2015.

[10] Geneca, "Doomed from the start," Secure.Facs.Org, vol. 2011, pp.1$13,2011$.

[11] R. Loi, L. W. Lam, H. Y. Ngo, and S. Cheong, "External factors influencing the readiness for implementing public-private partnerships among public and private organizations in Yemen," J. Manag. Psychol., vol. 30, pp. 645-658, 2015.

[12] V. Saini and D. C. Chou, "Information Technology Outsourcing: Issues and Future Analyses," no. October, pp. 400-407, 2016.

[13] S. F. Martin, D. Beimborn, M. A. Parikh, and T. Weitzel, "Organizational readiness for business process outsourcing: A model of determinants and impact on outsourcing success," in Proc. Annual Hawaiian Int. Conf. Syst. Sci., no. October 2016, 2008.

[14] R. Datsenka, "Client' s Readiness for IT Offshoring in Germany: A Model of Maturity , Capability and Business - IT Alignment," M. Eng. thesis, European University Viadrina, 2013.

[15] HRSA, "Readiness Assessment \& Developing Project Aims," 2015. [Online]. Available: http://www.hrsa.gov/quality/toolbox/methodology/readinessassessme $\mathrm{nt} /$

[16] Gartner, "IT Glossary," 2016. [Online]. Available: http://www.gartner.com/it-glossary/applications-outsourcing/

[17] T. Kern and L. Willcocks, "Exploring information technology outsourcing relationships: theory and practice," J. Strateg. Inf. Syst., vol. 9, pp. 321-350, 2000.

[18] D. Brown and P. Fersht, "Executive Report: The State of Services and Outsourcing in 2014," 2014. [Online]. Available: http://www.kpmginstitutes.com/content/dam/kpmg/sharedservicesout sourcinginstitute/pdf/2014/state-of-outsourcing-2014-exec-findingshfs.pdf

[19] V. Saini and D. C. Chou, "Information Technology Outsourcing: Issues and Future Analyses," no. October, pp. 400-407, 2016.

[20] K. Kronawitter, C. Wentzel, G. Turetschek, and M. Papadaki, "Critical Success Factors in IT-Outsourcing : a Literature Analysis," no. 1995, pp. 110-122, 2009.

[21] Perbendaharaan, "Garis Panduan Mengenai Pengurusan perolehan (ICT) Kerajaan," vol. 1, no. iii, 2013.

[22] PWC, "Sourcing Readiness Assessment (SRA)," 2015.

[23] N. M. Aziz and H. Salleh, "A readiness model for IT investment in the construction industry," African Journal of Business Management, vol. 5, pp. 2524-2530, 2011. 
[24] Stratis Health Information Technology Services, "Organizational Readiness Assessment," 2015.

[25] Z. Sándorová, "Content Analysis as a Research Method in Investigating the Cultural Components in Foreign Language Textbooks," J. Lang. Cult. Eduvation, vol. 2, pp. 95-128, 2014

[26] D. Sammon and F. Adam, "Towards a Model for Evaluating Organizational Readiness for ERP and Data Warehousing Projects," in European Conference on Information System, paper 107, 2004.

[27] S. Khan, M. Niazi, and R. Ahmad, "A readiness model for software development outsourcing vendors," in Proc. of the 3rd IEEE Int Conf. Glob. Softw. Eng. ICGSE 2008, no. February 2008, pp. 273 277.

[28] J. Mirzaei and F. M. Madani, "Proposing a conceptual readiness assessment model of mis/is deployment in manufacturing companies (a case study conducted on the applications of the suggested model in mehrcampars co.)," in Proc. of the Int. Conf. Information, Process. Knowl. Manag. eKNOW, 2009, pp. 141-146.

[29] Monetary Authority of Singapore, "Technology questionnaire for outsourcing." 2011.

[30] C. Ranganathan and S. Balaji, "Critical Capabilities for Offshore Outsourcing of Information Systems,” MIS Q. Exec., vol. 6, pp. 147164, 2007.

[31] D. Blackman, J. O'Flynn, and L. Ugyel, "A Diagnostic Tool for Assessing Organisational Readiness for Complex Change," in Anzam Australia and Neazland Academy of Management, 2013, pp. 4-6.

[32] G. A. Consulting, "Project Readiness Evaluation Process," 2013.
[33] J. Johari and E. N. M. Nazir, "Elevating organizational commitment through corporate culture: A case of public service agencies in Malaysia," J. Pengur., vol. 43, pp. 37-46, 2015.

[34] L. R. Shang Gao, Modern Techniques for Successful IT Project Management. 2015

[35] J. Chang and C. M. De Bú, "Towards a Framework for IT Offshore Outsourcing in Small and Medium-Sized Enterprises," International Journal of Innovation, Management and Technology, vol. 7, pp. 115$119,2016$.

[36] A. Fallis, "IT Readiness Assessment for Government Organizations," J. Chem. Inf. Model., vol. 53, pp. 1689-1699, 2013.

[37] F. F. Ismail and R. Razali, "Contributing Factors of Successful Software Testing Outsourcing," in 8th Malaysian Softw. Eng. Conf. 2014, pp. 55-60.

[38] M. Jørgensen, "A survey on the characteristics of projects with success in delivering client benefits," 2016.

[39] Unit Perancang Ekonomi Jabatan Perdana Menteri, "Panduan Pelaksanaan Pengurusan Nilai Dalam Program/Projek Kerajaan," Buku Pandu. VM, 2011

[40] M. M. S. T. Hub, "Bengkel Pengujian Perisian Sektor Awam," 2015.

[41] [41]M. Hamilton, "Organizing for Successful Software Development," Enterp. Comput. Inst., vol. 1, pp. 416, 2012.

[42] W. Al-Ahmad and A. Al-Oqaili, "Towards a unified model for successful implementation of outsourcing and reversibility of information systems," J. King Saud Univ. - Comput. Inf. Sci., vol. 25, pp. 229-240, 2013. 